\title{
Integration of Grey Relational Analysis and Goal Programming for Supplier selection and planning (Case Study from an Automotive Company)
}

\author{
Ahmad Jafarnejad Chaghooshi \\ Professor, Department of Management, University of Tehran, Tehran, Iran
}

Saeid karbasian (Corresponding author)

PhD student of Operations and Production Management, University of Tehran, Tehran, Iran

Tel: 98-912-396-7536_E-mail: karbasian@ut.ac.ir

Received: September 6, 2013 Accepted: Sep. 24, 2013 Published: December 25, 2013

doi:10.5296/bms.v4i2.4250 URL: http://dx.doi.org/10.5296/bms.v4i2.4250

\begin{abstract}
In today's competitive market, manufacturers not only intend to improve internal conditions, but choosing the best of markets and suppliers is at the top of their agenda. Selecting the best alternatives in each of these decisions requires analysis of many factors, which as a result, encounters organizations with a problem of multi-criteria decisions. On the other hand, the application of the grey relational analysis (GRA) in connection with consideration of the criteria in different managerial and operational issues has been referred to in many articles along which goal programming may consider several goals according to the priorities of the decision maker. The combination of these two techniques may create a model that takes into consideration various goals through simultaneous consideration of varied criteria.

In this article, a model of decision making is presented, which evaluates potential suppliers with the help of combination of the grey theory system and goal programming and consideration of various constraints, and ultimately, the best options are selected and the purchasing plan from each in every period is determined as well. For the purpose of examination, the model's reliability has been evaluated by case basis in a big automotive
\end{abstract}


manufacturing plant, and senior managers have approved the results.

Keywords: Grey Relational Analysis (GRA), Goal Programming (GP), Supplier selection 


\section{Introduction}

In today's severe competitive business environment, a well-designed and implemented supply chain management (SCM) system is regarded as an important tool to increase competitive advantage (Choi et al, 2007). Suppliers have a significant impact on final product quality and customer satisfaction. To successfully produce high-quality products with low-costs, long term and strategic relationships with suppliers is of critical importance as materials represent a substantial part of the value of products.

Accordingly, the selection of appropriate suppliers has long been a vibrant area in supply chain management, as many issues in the supply chain are influenced by the appropriate selection of suppliers (Kumar et al, 2006). Supplier selection is the process of selection of right suppliers who are able to provide right quality products and/or services at the right price, in the right quantities and at the right time (Sarkis et al, 2002), so that different objectives of the supply chain are achieved. The right source can provide the right quality of material on time at a reasonable price (Heizer et al, 2001). Thus, supplier selection is a very significant strategic decision (He et al, 2009). According to Huang (2000) supplier selection is important as it impacts not only on activities such as inventory management, production planning and control, cash flow requirements and product quality, but also product design and development. The success of an enterprise is highly dependent on selection of good supplier (Diaz-Madronero et al, 2010).

Traditionally, decision makers select suppliers based on their experience and intuition. The weakness of these approaches has been addressed in previous studies (Shyur et al, 2006). Supplier selection has been considered as a complex problem due to several reasons (Kumar et al, 2006). Within its nature, supplier selection is a Multi-Criteria Decision Making (MCDM) problem in which multiple criteria need to be carefully examined that can be both qualitative and quantitative. The MCDM provides an effective framework for supplier comparison, based on evaluation of multiple and often conflicting criteria. Moreover, supplier selection is an evaluation process that is unstructured and uses inaccurate or uncertain data. Full information about the suppliers on each criterion at the decision process is not known with certainty (Diaz-Madronero et al, 2010). Due to this vagueness and impreciseness of the information, selection of suppliers based on deterministic data is neither possible nor reasonable. Fuzzy set theory provides a framework for systematic handling the uncertainties of this type (Kumar et al, 2006).

Grey theory is one of the methods used to study uncertainty, being superior in the mathematical analysis of systems with uncertain information. In grey theory, according to the degree of information, if the system information is fully known, the system is called a white system; if the information is unknown, it is called a black system. A system with information known partially is called a grey system. The advantage of grey theory over fuzzy theory is that grey theory considers the condition of the fuzziness; that is, grey theory can deal flexibly with the fuzziness situation (Deng, 1989). 


\subsection{Methods of Supplier Selection Problem}

According to research work of Wang (2009), the quantitative decision methods for solving the supplier selection problem can be classified into three categories: (1) multi-attribute decision-making, (2) mathematical programming models and (3) intelligent approaches. Furthermore, in literature survey by Ho (2010), the mathematical programming models are grouped into the following five categories: (1) linear programming, (2) integer linear programming, (3) integer non-linear programming, (4) goal programming and (5) multi-objective programming. Table 1 summarizes the optimization models for supplier (Feng, Fan, \& Li, 2011).

Table 1. Research on mathematical programming models for supplier selection

\begin{tabular}{|c|c|c|}
\hline Model & Objective function & Constraint \\
\hline \multirow[t]{3}{*}{$\begin{array}{l}\text { Linear } \\
\text { programming }\end{array}$} & $\begin{array}{l}\text { Max(overall } \\
\text { performance) }\end{array}$ & $\begin{array}{l}\text { Productivity score based on the best measures, } \\
\text { efficiency score of each vendor }\end{array}$ \\
\hline & $\begin{array}{l}\text { Max(overall } \\
\text { performance) }\end{array}$ & Attribute weights \\
\hline & $\begin{array}{l}\text { Max (total value of } \\
\text { purchasing) }\end{array}$ & $\begin{array}{l}\text { Demand, quality, budgeting and suppliers' } \\
\text { capacity }\end{array}$ \\
\hline \multirow[t]{3}{*}{$\begin{array}{l}\text { Integer linear } \\
\text { programming }\end{array}$} & $\begin{array}{l}\text { Min (number of } \\
\text { suppliers) }\end{array}$ & $\begin{array}{l}\text { Efficiency of suppliers, amount order from } \\
\text { vendor, buyer's demand requirement, capacity of } \\
\text { vendor, and minimum order quantity requirement } \\
\text { of vendor }\end{array}$ \\
\hline & Max (revenue) & $\begin{array}{l}\text { Purchasing demand in meaningful purchasing } \\
\text { unit, supplier's potential system constraints and } \\
\text { purchaser's policy constraints, number of } \\
\text { suppliers, minimization of the supplier number } \\
\text { and changing cost }\end{array}$ \\
\hline & Min (purchasing cost) & $\begin{array}{l}\text { Order quantity, quality rate, late delivery rate and } \\
\text { number of suppliers }\end{array}$ \\
\hline $\begin{array}{l}\text { Integer } \\
\text { non-linear } \\
\text { programming }\end{array}$ & $\begin{array}{l}\text { Min (total annual } \\
\text { purchasing cost) }\end{array}$ & $\begin{array}{l}\text { Vendor's capacity, buyer's demand and } \\
\text { purchased volume }\end{array}$ \\
\hline $\begin{array}{l}\text { Goal } \\
\text { programming }\end{array}$ & $\begin{array}{l}\text { Min (annual product } \\
\text { cost) }\end{array}$ & $\begin{array}{l}\text { Quality of castings purchased, delivery reliability } \\
\text { of castings purchased, capacities of each supplier } \\
\text { and demand }\end{array}$ \\
\hline \multirow[t]{2}{*}{$\begin{array}{l}\text { Multi-objective } \\
\text { programming }\end{array}$} & $\begin{array}{l}\text { Min (cost, scrap } \\
\text { ratios, tardy-delivery } \\
\text { fraction })\end{array}$ & $\begin{array}{l}\text { Purchasing budget, buyer's demand, inventory } \\
\text { capacity and supplier's capacity }\end{array}$ \\
\hline & $\begin{array}{l}\text { Min(price, lead-time, } \\
\text { quality) }\end{array}$ & $\begin{array}{l}\text { Vendor's maximum capacity, product demand, } \\
\text { maximum number of vendors and price discounts }\end{array}$ \\
\hline
\end{tabular}




\section{Macrothink}

Chai (2012) summarize 26 DM techniques that had been used for supplier evaluation and selection. He classifies these techniques into three categories, namely: Multi-criteria decision making (MCDM) techniques, Mathematical programming (MP) techniques, and Artificial intelligence (AI) techniques. In Table 2, provide the names of the techniques and their abbreviations.

Table 2. The used DM techniques: Multi attribute decision making (MCDM) techniques

Multi attribute decision making (MCDM) techniques

1. Analytic hierarchy process (AHP)

2. Analytic network process (ANP)

3. Elimination and choice expressing reality (ELECTRE)

4. Preference ranking organization method for enrichment evaluation (PROMETHEE )

5. Technique for order performance by similarity to ideal solution (TOPSIS )

6. Multi-criteria optimization and compromise solution (VIKOR )

7. Decision making trial and evaluation laboratory (DEMATEL )

8. Simple multi-attribute rating technique (SMART)

Mathematical programming (MP) techniques

1. Data envelopment analysis( DEA)

2. Linear Programming (LP)

3. Nonlinear programming (NLP)

4. Multi-objective programming (MOP)

5. Goal programming (GP)

6. Stochastic programming (SP)

Artificial intelligence (AI) techniques

1. Genetic algorithm (GA)

2. Grey system theory (GST)

3. Neural networks (NN)

4. Rough set theory (RST)

5. Bayesian networks (BN)

6. Decision tree (DT)

7. Case-based reasoning (CBR)

8. Particle swarm optimization (PSO)

9. Support vector machine (SVM)

10. Association rule (AR)

11. Ant colony algorithm (ACA)

12. Dempster Shafer theory of evidence (DST)

In addition integrated techniques to consider many different aspects of supplier selection are proposed. Some of them are mentioned in Table 3 (Ho et al, 2010). 
Table 3. Integrated techniques to consider many different aspects

\begin{tabular}{|c|c|c|c|}
\hline \multirow{3}{*}{$\begin{array}{l}\text { Integrated } \\
\text { AHP } \\
\text { approaches }\end{array}$} & $\begin{array}{l}\text { Integrated AHP and } \\
\text { Bi-negotiation }\end{array}$ & Integrated AHP and GP & $\begin{array}{l}\text { Integrated AHP and } \\
\text { multi-objective } \\
\text { programming }\end{array}$ \\
\hline & $\begin{array}{l}\text { Integrated AHP and } \\
\text { DEA }\end{array}$ & $\begin{array}{l}\text { Integrated AHP and grey } \\
\text { relational analysis }\end{array}$ & \\
\hline & $\begin{array}{l}\text { Integrated AHP, } \\
\text { DEA, and artificial } \\
\text { neural network }\end{array}$ & $\begin{array}{l}\text { Integrated AHP and mixed } \\
\text { integer non-linear } \\
\text { programming }\end{array}$ & \\
\hline \multirow{2}{*}{$\begin{array}{l}\text { Integrated } \\
\text { fuzzy } \\
\text { approaches }\end{array}$} & $\begin{array}{l}\text { Integrated fuzzy and } \\
\text { AHP }\end{array}$ & $\begin{array}{l}\text { Integrated fuzzy, AHP, and } \\
\text { cluster analysis }\end{array}$ & Integrated fuzzy and GA \\
\hline & $\begin{array}{l}\text { Integrated fuzzy and } \\
\text { multi-objective } \\
\text { programming }\end{array}$ & $\begin{array}{lr}\text { Integrated fuzzy } & \text { and } \\
\text { quality } & \text { function } \\
\text { deployment } & \end{array}$ & $\begin{array}{l}\text { Integrated fuzzy and } \\
\text { SMART }\end{array}$ \\
\hline \multirow{3}{*}{$\begin{array}{l}\text { Other } \\
\text { approaches }\end{array}$} & $\begin{array}{l}\text { Integrated ANN and } \\
\text { CBR }\end{array}$ & Integrated ANN and GA & $\begin{array}{l}\text { Integrated ANP and } \\
\text { multi-objective } \\
\text { programming }\end{array}$ \\
\hline & $\begin{array}{l}\text { Integrated ANP and } \\
\text { GP }\end{array}$ & $\begin{array}{l}\text { Integrated DEA } \\
\text { multi-objective } \\
\text { programming }\end{array}$ & $\begin{array}{l}\text { Integrated DEA and } \\
\text { SMART }\end{array}$ \\
\hline & $\begin{array}{l}\text { Integrated GA and } \\
\text { multi-objective } \\
\text { programming }\end{array}$ & & \\
\hline
\end{tabular}

People often employ natural language to express thinking and subjective perception; and in these natural languages the meaning of words is often vague. The meaning of a word might be well defined, when using the word as a label for a set, the boundaries with which objects do or do not belong to the set become uncertainty. Hence, the proposed method is using GRA to appropriately express the determination of human judgment in the proposed criteria (Tseng, 2009).

Golmohammadi (2012) provided two-phase model which integrates the fuzzy pair wise comparison with a grey relational analysis. In the first phase, the proposed model utilizes the fuzzy pair wise comparisons technique to tackle some of the limitations in the current grey methodology. In the second phase, a method is proposed to mitigate the bias judgment and inconsistency in pair wise comparisons application in order to improve the results of the first phase.

Pitchipoo (2012) developed an appropriate hybrid model by integrating the analytical hierarchy process and grey relational analysis for supplier evaluation and selection, which comprises three stages.

Wu (2009) used grey related analysis and Dempster-Shafer theory to deal with this fuzzy 
group decision making problem. First, in the individual aggregation, grey related analysis is employed as a means to reflect uncertainty in multi-attribute models through interval numbers. Second, in the group aggregation, the Dempster-Shafer rule of combination is used to aggregate individual preferences into a collective preference, by which the candidate alternatives are ranked and the best alternative(s) are obtained.

The advantages of the GRA over traditional tools in decision making and supplier selection is related to its ability to capture, process, and integrate uncertainty in the decision making process. While several tools and methodologies such as probabilistic analysis, stochastic programming, and chance-constraint programming have been developed to address, they are not capable of handling complex problems involving both complete and incomplete information. Since GRA uses original data, the results are more relevant to practice. For these reasons, GRA has been recommended as one the best methods to be used in making decisions in the business environment (Golmohammadi et al,2012).

In this paper, we offer a new method so called integrated GP \& GRA for selecting supplier under uncertainty and unsure conditions. The main steps of this method are explained as follows: at first, using grey numbers, we specify the attributes of all suppliers. Secondly, we rank all suppliers according to their degree of grey possibility. The uncertainty and inconsistency of the attributes should be considered in all steps.

Regarding that MODM (Multiple Objective Decision Making) aiming improvement focuses on several objectives simultaneously and MADM (Multiple Attribute Decision Making) takes into account multi-criteria, in offered model we benefit from the integration of these two approaches. The MADM and MODM is a proper and practical resolve for compensating the possible mistakes of decision making based on uncertain conditions. Besides in this approach we are able to present a real model which notices all the constraints of budget, quantity and failure ratios in different time periods. Finally, a real example of supplier selection in automotive factory is used to illustrate the proposed approach.

\subsection{Criteria of Supplier Selection Problem}

Dickson (1966) listed 23 criteria for supplier's selection, based on a survey of 273 purchasing manager. The analysis showed that quality, delivery and performance history could be considered, in their respective order, the three most important criteria. Haa \& Krishnanb (2008) updated this set of attributes. This attribute list provides a first flavor of the complexity of the problem: many factors should be taken into account, very often confusing each other. Moreover, some of these factors can be easily measured, while some others are qualitative concepts: the aggregation of these attributes in a final judgment about a supplier can result in a tricky problem.

A recent study by Rezaei (2013) mentioned there are two dimensions (capabilities and willingness) on the basis of which suppliers can be segmented. The dimensions, capabilities and willingness, are seen as multi-criteria concepts. For example, the capabilities of a supplier can be evaluated using different criteria such as the quality of the products, the technical 


\section{Macrothink}

capability of the supplier in question. Willingness of the supplier can be evaluated using multiple criteria, such as communication openness and commitment to continuous improvement in product and process.

\section{Grey Relational Analysis}

A grey system is defined as a system containing uncertain information presented by a grey number and grey variables.

Let $\mathrm{X}$ is the universal set. Then a grey set $G$ of $X$ is defined by its two mappings:

$$
\bar{\mu}_{G}(x): x \rightarrow[0,1], \quad \underline{\mu}_{G}(x): x \rightarrow[0,1]
$$

$\bar{\mu}_{G}(x)$ : Upper membership functions

$\bar{\mu}_{G}(x)$ : Lower membership functions

$x \in X, \mathrm{X}=\mathrm{R}$.

The grey number can be defined as a number with uncertain information. For example, the ratings of attributes are described by the linguistic variables; there will be a numerical interval expressing it. This numerical interval will contain uncertain information. Generally, grey number is written as

$$
\otimes G=\left.G\right|_{\underline{\mu}} ^{\bar{\mu}}
$$

The lower and upper limits of $G$ can be estimated and $G$ is defined as an interval grey number.

$$
\otimes G=[\underline{G}, \bar{G}]
$$

Basic operation laws of grey numbers:

$$
\otimes G_{1} \pm \otimes G_{2}=\left[\underline{G}_{1} \pm \underline{G}_{2}, \bar{G}_{1} \pm \bar{G}_{2}\right]
$$




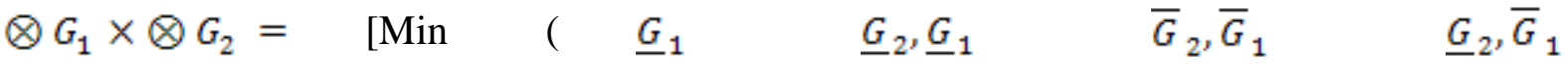

$$
\begin{aligned}
& \left.\left.\bar{G}_{2}\right), \operatorname{Max}\left(\underline{G}_{1} \underline{G}_{2}, \underline{G}_{1} \bar{G}_{2}, \bar{G}_{1} \underline{G}_{2}, \bar{G}_{1} \bar{G}_{2}\right)\right] \\
& \otimes G_{1} \div \otimes G_{2}=\left[\underline{G}_{1}, \bar{G}_{1}\right] \\
& \times\left[\frac{1}{\underline{G}_{2}}, \frac{1}{\bar{G}_{2}}\right] .
\end{aligned}
$$

The length of grey number $\mathrm{G}$ is defined as:

$L(\otimes G)=[\bar{G}-\underline{G}]$.

The possibility degree of $\otimes \mathrm{G} 1 \leq \otimes \mathrm{G} 2$ can be expressed as follows:

$P\left\{\otimes \mathrm{G} 1 \leq \otimes G_{2}\right\}=\frac{\operatorname{Max}\left(0, L^{*}-\operatorname{Max}\left(0, \bar{G}_{1}-\underline{G}_{2}\right)\right)}{L^{*}}$

Where $L^{*}=L(\otimes \mathrm{G} 1)+L(\otimes G(2)$

\section{Proposed Methodology}

As mentioned, according to Rezaei (2013), selection criteria were classified into the following divisions which can be seen in Table 4. In the end, all of the suppliers were evaluated, classified, and categorized in terms of quality using fuzzy theory.

Table 4. Selected capabilities and willingness criteria

\begin{tabular}{|l|l|}
\hline Selected capabilities criteria & Selected willingness criteria \\
\hline Price & Commitment to quality \\
\hline Delivery & Communication openness \\
\hline Quality & Reciprocal arrangement \\
\hline Reserve capacity & Willingness to share information \\
\hline Geographical location & Supplier's effort in promoting JIT principles \\
\hline Financial position & Long term relationship \\
\hline
\end{tabular}


In the current article, willingness criteria in quality evaluation by GRA and the capabilities criteria are considered as quantity constraints. Ultimately, the Goal programming was utilized for final summarization and evaluation. The case study for the same model is conducted in the real environment in an automotive manufacturing unit, and the company's managers were provided with the results for decision-making.

The model that will be introduced attempts to pre-assessment the suppliers considering the quality criteria and GRA. In addition, it works out the weights of suppliers using the GRA, and then through minimizing purchasing costs and considering quantity constraints in a Goal Programming framework, the appropriate supplier is selected.

On this basis, categorization of the criteria is carried out in two divisions according to the nature of the criteria are presented in Table 5.

Table 5. Classification of quantitative and qualitative criteria

\begin{tabular}{|l|l|}
\hline Quality criteria & Quantity criteria \\
\hline Price & Commitment to quality \\
\hline Delivery & Communication openness \\
\hline Quality & Reciprocal arrangement \\
\hline Reserve capacity & Willingness to share information \\
\hline Geographical location & Supplier's effort in promoting JIT principles \\
\hline Financial position & Long term relationship \\
\hline
\end{tabular}

Quantity criteria in the form of quantity constraints and through GRA are used in order to convert quality relationships into quantified ones, and at the end, goal programming is used to consider all the relationships (see Table 6).

Table 6. Converted quantitative criteria to constraints

\begin{tabular}{|l|l|}
\hline constraints & Quantity criteria \\
\hline \multirow{2}{*}{$\begin{array}{l}\text { Constraints of supplier capacities and } \\
\text { purchasing budget }\end{array}$} & Price \\
\cline { 2 - 2 } & Financial position \\
\hline Limitation of the number of suppliers & Delivery \\
\cline { 2 - 2 } & Geographical location \\
\hline \multirow{2}{*}{$\begin{array}{l}\text { Demanded capacity according to the rate } \\
\text { of failure }\end{array}$} & Quality \\
\cline { 2 - 2 } & Reserve capacity \\
\hline
\end{tabular}

As it was set out in the literature's context, in many of the presented articles, suppliers are selected regardless of the supply plan in different periods, and they presented models in this field have been in relation to only one of the pre-evaluation stages, selection and suppliers plan. In the presented model, the suppliers are selected according to the conditions of each period, and in this respect, the new model is in closer correspondence with the real conditions. The presented model works out and introduces a plan to purchase parts and materials based 
on data in the Master Production Schedule (MPS) table as well as the existing conditions and Manufacturing resource planning (MRP). It should be noted that the Lot for Lot method (order as per requirements) is considered the basis of purchase plans. The suggested model is a MADM model and on the other hand a MODM one. The presented model is an integrated and comprehensive model that intends to present the most optimal response to the decision maker in terms of minimizing total costs along with considering quantity and quality criteria of decision-making. Determining and planning of the suppliers by the buyers is taken into consideration in this article through the following four general steps:

1) Search for suppliers of parts, and determining quantity and quality criteria as well as receiving specifications from the suppliers;

2) Pre-evaluation of the supplier by the GRA followed by primary ranking of suppliers based on grey relations;

3) Formulating and considering relevant constraints and variations, and

4) Final evaluation of the suppliers by the GP (Cost functions and weighting functions derived from the pre-assessment stage) and determining the required amount of order placing with the suppliers in each period

The following will set out each one of the stages.

3.1 Search for the Suppliers of Parts and Determining Quantity and Quality Criteria as Well as Receiving Specifications from the Supplier as in MRP and MPS Plans

In this article, as it is already explained, Table 5 has been applied to classify quantity and quality criteria.

\subsection{Pre-Evaluation of the Suppliers Using GRA}

3.2.1 At First, Weight of Each of the Criteria was Mentioned according to the Linguistic Variables. Linguistic Variables are Determined Based on a Grey Number as Follows

$\otimes W_{i}=\left[\overline{w_{1}}, \underline{w}_{i}\right]$

$W_{i}=\frac{1}{K}\left[W_{i}^{1}+W_{i}^{2}+\cdots+W_{i}^{k}\right]$

$1 \leq i \leq m$

In which $\mathrm{K}$, the decision maker of each criteria of $\mathrm{i}$, using linguistics variables and mentions self-weights. The respective weight of each criterion is worked out from the weight average related to the decision makers.

The scale of criteria may be considered according to the Table 7 . 
Table 7. The scale of criteria weights

\begin{tabular}{|l|l|}
\hline Scale & $\otimes W$ \\
\hline Very low (VL) & {$[0.0,0.1]$} \\
\hline Low (L) & {$[0.1,0.3]$} \\
\hline Medium low (ML) & {$[0.3,0.4]$} \\
\hline Medium (M) & {$[0.4,0.5]$} \\
\hline Medium high (MH) & {$[0.5,0.6]$} \\
\hline High $(\mathrm{H})$ & {$[0.6,0.9]$} \\
\hline Very high $(\mathrm{VH})$ & {$[0.9,1.0]$} \\
\hline
\end{tabular}

3.2.2 For Each of the Suppliers, the Decision Makers Present Their Scores Using the Linguistic Variables. The Weight Average is Used In Order to Calculate the Final Weight

Where $G_{i j}^{k}$ is rank of supplier $\mathrm{j}$ at the criteria i in the Kth decision maker's view.

$$
G_{i j}=\frac{1}{K}\left[G_{i j}^{1}+G_{i j}^{2}+\cdots+G_{i j}^{k}\right]
$$

$1 \leq i \leq m$

$$
1 \leq j \leq n
$$

The decision-making matrix is as follows:

$$
D=\left[\begin{array}{ccc}
G_{11} & \cdots & G_{1 m} \\
\vdots & \ddots & \vdots \\
G_{n 1} & \cdots & G_{n m}
\end{array}\right]
$$

The table of linguistic variables to score the suppliers is as follows (see Table 8). 


\section{Macrothink}

Table 8. Linguistic variables to score the suppliers

\begin{tabular}{|l|l|}
\hline Very poor (VP) & $0,1]$ \\
\hline Poor (P) & {$[1,3]$} \\
\hline Medium poor (MP) & {$[3,4]$} \\
\hline Fair (F) & {$[4,5]$} \\
\hline Medium good (MG) & {$[5,6]$} \\
\hline Good (G) & {$[6,9]$} \\
\hline Very good (VG) & {$[9,10]$} \\
\hline
\end{tabular}

3.2.3 The Acquired Matrix Must be Normalized

$D=\left[\begin{array}{ccc}\otimes G^{*}{ }_{11} & \cdots & \otimes G^{*}{ }_{1 m} \\ \vdots & \ddots & \vdots \\ \otimes G^{*}{ }_{n 1} & \cdots & \otimes G^{*}{ }_{n m}\end{array}\right]$

$\otimes G_{i j}^{*}=\left[\frac{G_{i j}}{G_{j}^{\max }}, \frac{\overline{G_{i j}}}{G_{j}^{\max }}\right]$

$G_{j}^{\max }=\max [\overline{G i j}] 1 \leq i \leq m \quad 1 \leq j \leq n$.

3.2.4 The Grey Decision-Making Matrix is Result of Normalized Grey Decision-Making Matrix Multiplied by Factor Weights

$D=\left[\begin{array}{ccc}\otimes V_{11} & \cdots & \otimes V_{1 m} \\ \vdots & \ddots & \vdots \\ \otimes V_{n 1} & \cdots & \otimes V_{n m}\end{array}\right]$

$\otimes V_{i j}=\otimes G_{i j}^{*} \times \otimes W_{j}$

3.2.5 In order to Compare and Rank the Options (Suppliers), the Ideal Option is Worked out according to the Following Items

$S^{\max }=\left\{\otimes \mathrm{G}_{1}^{\max }{ }_{j} \otimes \mathrm{G}_{2}^{\max }, \ldots, \otimes \mathrm{G}_{\mathrm{n}}^{\max }\right\}$. 
3.2.6 The Grey Possibility Degree between Compared Alternatives is Calculated

$$
P\left\{S_{i} \leq S^{\max }\right\}=\frac{1}{n} \sum_{j=1}^{n} P\left\{\otimes V_{\mathrm{ij}} \leq \otimes G_{j}^{\max }\right\} .
$$

The less grey possibility degree is, the better, and ordering is done based on the same.

\subsubsection{The Normalization of the Less Grey Possibility Degree is Carried out as Above}

\subsection{Formulating and Considering Constraints and Respective Variables}

At this stage, the effective constraints as well as capacity constraints according to the failure rate, constraints pertinent to the supplier's capacity, the number of suppliers in every period according to the MRP table, and the amount of time for receiving the order pertinent to the supplier is added to the model.

\subsubsection{Formulating the Constraints Pertinent to Normalized Grey Possibility Degree}

The following equation may be written:

$$
\sum_{j=1}^{M} P_{j} S_{j}+d^{-}-d^{+}=\operatorname{Min}\left(\sum_{j=1}^{N} P_{j}\right)
$$

$P_{j}=P\left\{S_{j} \leq S^{\max }\right\}$

For $L T_{j} \leq T \quad t=1, \ldots, T$

The right side of the equation is equals to the least weights of supplier, which are selected in each period.

The Lead time (LT) for each supplier must be less than the time cycle (T).

In case the scores in different periods are separate, for each period there will be:

$$
\sum_{j=1}^{M_{t}} P_{j t} S_{j t}+d_{t}^{-}-d_{t}^{-}=\operatorname{Min}\left(\sum_{j=1}^{N_{t}} P_{j t}\right)
$$

$P_{j t}$ : Indicates the normalized grey possibility degree for supplier $\mathrm{j}$ in period t. The Lead Time 
of these suppliers must be less than or equal to the ordering period.

$S_{j t}$ : Zero-one variables indicate the selection or non-selection for supplier $\mathrm{j}$ in period $\mathrm{t}$.

$M_{t^{*}}$ Is the number of suppliers whose duration of order receipt is less than or equal to the period of ordering in period $t$.

$\mathrm{N}_{\mathrm{t}}$ : Equals the number of suppliers for selection in period $\mathrm{t}$.

$\mathrm{N}_{\mathrm{t}} \leq \mathrm{M}_{\mathrm{t}}$

$\mathrm{d}_{\mathrm{t}}^{-}, \mathrm{d}_{\mathrm{t}}^{+}$: Deviation variables in period $\mathrm{t}$.

$\mathrm{LT}_{\mathrm{j}}$ : Duration until the orders receipt for supplier $\mathrm{j}$.

The objective function pertinent to these constraints based on GP is as below:

$$
Z_{1}=\operatorname{Min} \sum_{t=1}^{T} d_{t}^{+}
$$

In a way that the target is selecting the smallest weights derived based on GRA.

\subsubsection{Constraints of the Purchasing Budget}

If the price and total costs paid to the supplier based on the activities by the supplier $\mathrm{j}$ in the period t equals $C_{j t}$ and the budget for the whole period of planning equals B (of course it may be separated based on each period and also if it is considered equal to zero, the same size as the least of the budget is required), the following limitation is added to the model as the purchasing budget limitation:

$$
\sum_{t=1}^{T} \sum_{J=1}^{M_{t}} C_{j t} X_{j t}+e^{-}-e^{+}=B
$$

$e^{-}, e^{+}:$Variables of budget deviation 


\section{Macrothink}

B: The budget for the whole period of planning

$C_{j t}$ : The costs paid to the supplier based on the activities performed by supplier $\mathrm{J}$ in period $\mathrm{t}$.

The second objective function pertinent to these constraints based on GP is as below:

$$
Z_{2}=\operatorname{Min} \sum_{t=1}^{T} e^{+}
$$

3.3.3 The Constraint Pertinent to the Demanded Capacity according to the Rate of Failure in the Delivered Items of Each Supplier

$\sum_{j=1}^{M_{t}}\left(1-f_{j}\right) X_{j t}=D_{t}$

For $L T_{j} \leq T \quad t=1, \ldots, T$

In the above constraint

$f_{j^{\Sigma}} \quad$ Failure rate of supplier $\mathrm{j}$

$X_{j t}:$ The amount of purchased spare parts from supplier $\mathrm{j}$ in period $\mathrm{t}$

$D_{t}$ : Required amount of part in period t according to the MRP table.

$M_{t^{\varepsilon}}$ Is the number of suppliers whose duration of order receipt is shorter than or equal to the period when there is an order.

Due to the division to division ordering, suppliers are selected who can deliver the required amount of order in the beginning of the scheduled period or later periods before the requested time according to other constraints.

\subsubsection{Constraints of Supplier Capacities}

If the amount of order from each supplier $\mathrm{j}$ in period thas the upper limit $U_{j t}$ and the lower 
limit $L_{j t}$ and $S_{\mathrm{jt}}$ zero-one variable, which indicates selection and non-selection of the supplier, $\mathrm{i}$ in $\mathrm{t}$ period, the following constraint is added to the model concerning the suppliers' capacity.

$$
S_{j \mathrm{t}}\left(L_{j t}\right) \leq X_{j t} \leq S_{j \mathrm{tt}}\left(U_{j t}\right)
$$

$$
\text { For } L T_{j} \leq T \quad t=1, \ldots, T
$$

\subsubsection{Limitation of the Number of Suppliers}

The policy ordering in the supplying chain is in a fashion that constantly stresses the decrease in the number of suppliers. Hence, imposing constraints on the number of suppliers for each period of ordering is added to the model.

$$
\sum_{J=1}^{M_{t}} S_{j t}=N_{\mathrm{t}}
$$

For $L T_{j} \leq T \quad t=1, \ldots, T$

$S_{j t}:$ Zero-One variable which indicates non-selection and selection of the supplier $\mathrm{j}$ in period t.

$N_{\mathrm{t}}$ : The desired number of suppliers in period t.

$M_{t}$ : The existing number of suppliers whose duration of order receipt are shorter than or equal to the current period.

3.4 Final Assessment to Determine Final Suppliers by Resolving Goal Programming through Consideration of the Costs Function and Weighting Functions Derived from the Pre-Assessment in the Previous Stage

In the end, if $a_{1}$ and $a_{2}$ show the weights pertinent to the mentioned target functions, the target function of goal programming will be as follows:

$\operatorname{Min}\left(a_{1} z_{1}+a_{2} z_{2}\right)=\operatorname{Min}\left(a_{1} \sum_{t=1}^{T} d_{t}^{+}+a_{2} \sum_{t=1}^{T} e^{+}\right)$.

If the weights are large relative to each other, the target function may be written as follows: 
$\operatorname{Min}\left(a_{1} z_{1}, a_{2} z_{2}\right)=\operatorname{Min}\left(a_{1} \sum_{t=1}^{T} d_{t}^{+}, a_{2} \sum_{t=1}^{T} e^{+}\right)$

By considering the objective function (goals) and the mentioned constraints, the final suppliers and the purchase plan are determined at the horizon of planning. It should be noted that the priority pertaining to the two target functions are dependent upon the decision maker's opinion and each organization's strategy against the purchase of required items from suppliers. In the case that the two suppliers are under the same condition of the cost's target function, a supplier will be selected from whom the purchase results in minimizing the normalized grey possibility degree objective, and vice versa.

\section{Adaptation of the Model to Select Suppliers in the Automotive Company}

The above model was reviewed in SAIPA cooperation, ZAMYAD company (an automotive company). This company, according to the type of industry and varied supplied parts, uses a large number of suppliers, and the company's managers admitted the need for a model for decision-making.

In this regard, the requirements plan for a particular spare part of the pickup is set out in Table 9 and 10. According to this table, in the second and third periods, 250 and 150 units put forward demands for purchase, respectively, and the effect of failure is not considered in this instance. In this regard, some suppliers are selected for assessment. In order to acquire weights pertinent to the criteria and their assessment, at first, a number of check lists were employed for which the senior managers were responsible, and the scoring was carried according to Tables 7 and 8 .

Table 9. Material requirement planning in three periods

\begin{tabular}{|l|l|l|l|l|}
\hline \multicolumn{2}{|l|}{} & \multicolumn{3}{l|}{ Period } \\
\hline \multicolumn{2}{|l|}{} & 1 & 2 & 3 \\
\hline Forecast requirement & & 350 & 150 \\
\hline In Transit & & & \\
\hline Projected available balance & 500 & 500 & & \\
\hline Planned shipments & & 150 & 150 \\
\hline
\end{tabular}

Table 10. Attributes of candidate suppliers in assessment and selection procedure

\begin{tabular}{|l|l|l|l|l|l|l|l|}
\hline \multirow{2}{*}{ Supplier } & \multirow{2}{*}{$\begin{array}{l}\text { LEAD } \\
\text { TIME }\end{array}$} & \multicolumn{3}{|l|}{ Cost per unit } & \multicolumn{2}{l|}{$\begin{array}{l}\text { Minimum } \\
\text { ordering }\end{array}$} & \multicolumn{2}{l|}{$\begin{array}{l}\text { Maximum } \\
\text { ordering }\end{array}$} \\
\cline { 3 - 8 } & & $\begin{array}{l}\text { Period } \\
2\end{array}$ & $\begin{array}{l}\text { Period } \\
3\end{array}$ & $\begin{array}{l}\text { Period } \\
2\end{array}$ & $\begin{array}{l}\text { Period } \\
3\end{array}$ & $\begin{array}{l}\text { Period } \\
2\end{array}$ & $\begin{array}{l}\text { Period } \\
3\end{array}$ \\
\hline 1 & 1 & 20 & 20 & 10 & 10 & 100 & 100 \\
\hline 2 & 2 & 20 & 20 & 10 & 10 & 100 & 100 \\
\hline 3 & 1 & 25 & 20 & 10 & 10 & 100 & 100 \\
\hline
\end{tabular}




\begin{tabular}{|l|l|l|l|l|l|l|l|}
\hline 4 & 3 & 21 & 20 & 10 & 10 & 100 & 100 \\
\hline
\end{tabular}

At first, the managers as in the Table 11 carried out the scoring, and the results in the following table were obtained. (See Tables 12, 13, 14, 15 and 16).

Table 11. Criteria weights based on four Decision makers' ranking

\begin{tabular}{|c|c|c|c|c|c|c|}
\hline \multirow[t]{2}{*}{ Criteria } & \multirow[t]{2}{*}{ Manager 1} & \multirow[t]{2}{*}{ Manager 2} & \multirow[t]{2}{*}{ Manager 3} & \multirow[t]{2}{*}{ Manager 4} & \multicolumn{2}{|l|}{$w_{i}$} \\
\hline & & & & & $\underline{w}_{\mathrm{i}}$ & $\bar{w}_{\mathrm{i}}$ \\
\hline Commitment to quality & $\mathrm{VH}$ & $\mathrm{MH}$ & $\mathrm{H}$ & $\mathrm{VH}$ & 0.73 & 0.88 \\
\hline $\begin{array}{l}\text { Communication } \\
\text { openness }\end{array}$ & $\mathrm{H}$ & $\mathrm{H}$ & M & VH & 0.63 & 0.83 \\
\hline Reciprocal arrangement & $\mathrm{H}$ & $\mathrm{H}$ & $\mathrm{H}$ & $\mathrm{H}$ & 0.60 & 0.90 \\
\hline $\begin{array}{l}\text { Willingness to share } \\
\text { information }\end{array}$ & $\mathrm{H}$ & $\mathrm{H}$ & $\mathrm{MH}$ & VH & 0.65 & 0.85 \\
\hline $\begin{array}{l}\text { Supplier's effort in } \\
\text { promoting JIT principles }\end{array}$ & $\mathrm{H}$ & $\mathrm{H}$ & VH & VH & 0.75 & 0.95 \\
\hline Long term relationship & $\mathrm{H}$ & $\mathrm{H}$ & VH & $\mathrm{MH}$ & 0.65 & 0.85 \\
\hline
\end{tabular}

The scores pertaining to the suppliers for criteria are shown in Table12 as well:

Table 12. Criteria rating values for suppliers based on four Decision makers' ranking according to Equation (11)

\begin{tabular}{|c|c|c|c|c|c|c|c|}
\hline \multicolumn{2}{|l|}{ Criteria } & \multirow{3}{*}{$\begin{array}{l}\text { Manager } \\
1 \\
\\
\text { MP }\end{array}$} & \multirow{3}{*}{$\begin{array}{l}\text { Manager } \\
2 \\
\\
\text { VG }\end{array}$} & \multirow{3}{*}{$\begin{array}{c}\text { Manager } \\
3 \\
\\
\text { VG }\end{array}$} & \multirow{3}{*}{$\begin{array}{l}\text { Manager } \\
4 \\
\\
\text { VG }\end{array}$} & \multicolumn{2}{|c|}{$G_{\mathrm{ij}}$} \\
\hline & & & & & & $\underline{G_{i j}}$ & $\overline{G_{i j}}$ \\
\hline \multirow{4}{*}{$\begin{array}{l}\text { Commitment to } \\
\text { quality }\end{array}$} & S1 & & & & & 3.75 & 4.75 \\
\hline & $\mathrm{S} 2$ & $\mathrm{MG}$ & $\mathrm{MG}$ & VG & MG & 6.5 & 7.5 \\
\hline & S3 & $\mathrm{VG}$ & $\mathrm{VG}$ & $\mathrm{MG}$ & $\mathrm{MG}$ & 6 & 7 \\
\hline & S4 & VG & $\mathrm{VG}$ & $\mathrm{MG}$ & $\mathrm{MG}$ & 7.5 & 8.5 \\
\hline \multirow{4}{*}{$\begin{array}{l}\text { Communication } \\
\text { openness }\end{array}$} & S1 & MP & $\mathrm{VG}$ & $\mathrm{VG}$ & $\mathrm{VG}$ & 7 & 8 \\
\hline & $\mathrm{S} 2$ & $\mathrm{MG}$ & $\mathrm{VG}$ & $\mathrm{VG}$ & MP & 6 & 7 \\
\hline & S3 & $\mathrm{MG}$ & $\mathrm{MG}$ & $\mathrm{MG}$ & $\mathrm{MG}$ & 7.5 & 8.5 \\
\hline & $\mathrm{S} 4$ & $\mathrm{VG}$ & $\mathrm{MG}$ & $\mathrm{MG}$ & MG & 6 & 7 \\
\hline \multirow{4}{*}{$\begin{array}{l}\text { Reciprocal } \\
\text { arrangement }\end{array}$} & S1 & MG & $\mathrm{MG}$ & $\mathrm{MG}$ & MG & 7 & 8 \\
\hline & S2 & $\mathrm{MG}$ & $\mathrm{MG}$ & $\mathrm{MG}$ & $\mathrm{MG}$ & 6.5 & 7.5 \\
\hline & S3 & $\mathrm{VG}$ & $\mathrm{VG}$ & $\mathrm{L}$ & $\mathrm{VG}$ & 7.5 & 8.5 \\
\hline & S4 & $\mathrm{VG}$ & $\mathrm{MG}$ & $\mathrm{MG}$ & $\mathrm{MG}$ & 6.25 & 7.25 \\
\hline
\end{tabular}




\begin{tabular}{|c|c|c|c|c|c|c|c|}
\hline \multirow{4}{*}{$\begin{array}{l}\text { Willingness to } \\
\text { share } \\
\text { information }\end{array}$} & S1 & MG & MG & VG & MG & 4.75 & 5.75 \\
\hline & $\mathrm{S} 2$ & $\mathrm{VG}$ & $\mathrm{VG}$ & $\mathrm{MG}$ & $\mathrm{MG}$ & 5.75 & 6.75 \\
\hline & S3 & $\mathrm{VG}$ & $\mathrm{VG}$ & MG & $\mathrm{MG}$ & 4 & 5 \\
\hline & S4 & $\mathrm{VG}$ & VG & VG & MG & 5 & 6 \\
\hline \multirow{4}{*}{$\begin{array}{ll}\text { Supplier's } & \\
\text { effort } & \text { in } \\
\text { promoting } & \text { JIT } \\
\text { principles } & \end{array}$} & $\mathrm{S} 1$ & MG & MG & VG & VG & 7.25 & 8.25 \\
\hline & $\mathrm{S} 2$ & $\mathrm{VG}$ & $\mathrm{MG}$ & VG & MG & 5.75 & 6.75 \\
\hline & S3 & MP & VG & VG & VG & 6 & 7 \\
\hline & S4 & MG & MG & $\mathrm{VG}$ & $\mathrm{MG}$ & 7 & 8 \\
\hline \multirow{4}{*}{$\begin{array}{l}\text { Long term } \\
\text { relationship }\end{array}$} & S1 & $\mathrm{VG}$ & $\mathrm{VG}$ & $\mathrm{MG}$ & $\mathrm{MG}$ & 6.5 & 7.5 \\
\hline & $\mathrm{S} 2$ & $\mathrm{VG}$ & $\mathrm{VG}$ & MG & $\mathrm{MG}$ & 7.75 & 8.75 \\
\hline & S3 & MP & $\mathrm{VG}$ & VG & $\mathrm{VG}$ & 6.5 & 7.5 \\
\hline & S4 & MG & $\mathrm{VG}$ & $\mathrm{VG}$ & MP & 7 & 8 \\
\hline
\end{tabular}

Table 13. Grey normalized table according to Equation (13)

\begin{tabular}{|c|c|c|c|c|c|}
\hline & & S1 & $\mathrm{S} 2$ & S3 & S4 \\
\hline \multirow{2}{*}{$\begin{array}{l}\text { Commitment to } \\
\text { quality }\end{array}$} & $\frac{G_{1 j}}{G_{j}^{\max }}$ & 0.441176 & 0.764706 & 0.705882 & 0.882353 \\
\hline & $\frac{\overline{G_{1 j}}}{G_{j}^{\max }}$ & 0.558824 & 0.882353 & 0.823529 & 1 \\
\hline \multirow{2}{*}{$\begin{array}{l}\text { Communication } \\
\text { openness }\end{array}$} & $\frac{G_{2 j}}{G_{j}^{\max }}$ & 0.823529 & 0.705882 & 0.882353 & 0.705882 \\
\hline & $\frac{\overline{G_{2 j}}}{G_{j}^{\max }}$ & 0.941176 & 0.823529 & 1 & 0.823529 \\
\hline $\begin{array}{l}\text { Reciprocal } \\
\text { arrangement }\end{array}$ & $\frac{G_{3 j}}{G_{j}^{\max }}$ & 0.823529 & 0.764706 & 0.882353 & 0.735294 \\
\hline
\end{tabular}




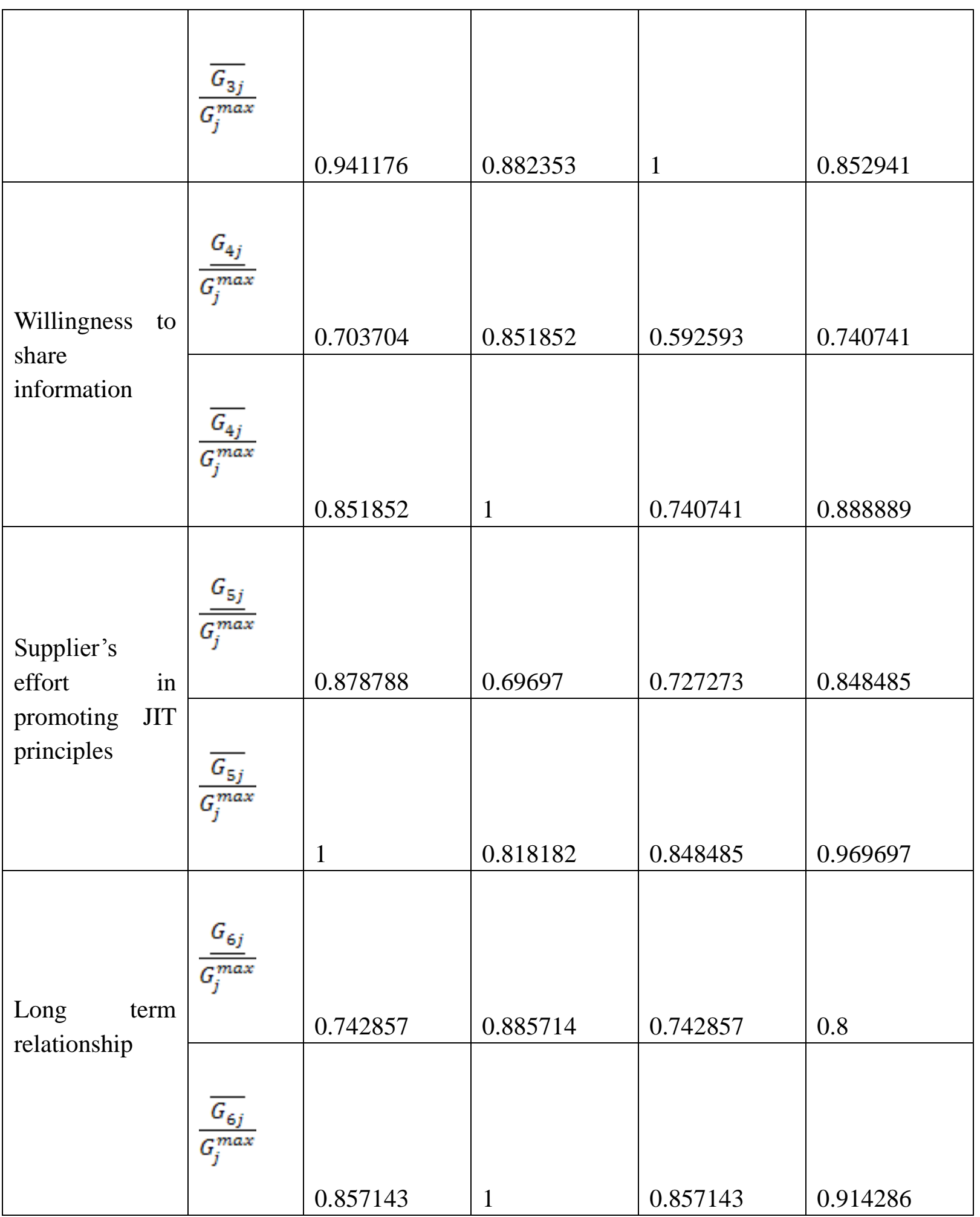

Table 14.Weighted normalized grey according to Equation (14)

\begin{tabular}{|l|l|l|l|l|l|}
\hline \multicolumn{2}{|l|}{} & S1 & S2 & S3 & S4 \\
\hline $\begin{array}{l}\text { Commitment to } \\
\text { quality }\end{array}$ & $\underline{V_{1 j}}$ & 0.32205848 & 0.55823538 & 0.51529386 & 0.64411769 \\
\hline
\end{tabular}




\begin{tabular}{|c|c|c|c|c|c|}
\hline & $\bar{V}_{1 j}$ & 0.49176512 & 0.77647064 & 0.72470552 & 0.88 \\
\hline \multirow{2}{*}{$\begin{array}{l}\text { Communication } \\
\text { openness }\end{array}$} & $\underline{V_{2 j}}$ & 0.51882327 & 0.44470566 & 0.55588239 & 0.44470566 \\
\hline & $\bar{V}_{2 j}$ & 0.78117608 & 0.68352907 & 0.83 & 0.68352907 \\
\hline \multirow{2}{*}{$\begin{array}{l}\text { Reciprocal } \\
\text { arrangement }\end{array}$} & $\underline{V_{3 j}}$ & 0.4941174 & 0.4588236 & 0.5294118 & 0.4411764 \\
\hline & $\bar{V}_{3 j}$ & 0.8470584 & 0.7941177 & 0.9 & 0.7676469 \\
\hline \multirow{2}{*}{$\begin{array}{l}\text { Willingness to } \\
\text { share } \\
\text { information }\end{array}$} & $\underline{V}_{4 j}$ & 0.4574076 & 0.5537038 & 0.38518545 & 0.48148165 \\
\hline & $\bar{V}_{4 j}$ & 0.7240742 & 0.85 & 0.62962985 & 0.75555565 \\
\hline \multirow{2}{*}{$\begin{array}{ll}\text { Supplier's } & \\
\text { effort } & \text { in } \\
\text { promoting } & \text { JIT } \\
\text { principles } & \end{array}$} & $\underline{V}_{5 j}$ & 0.659091 & 0.5227275 & 0.54545475 & 0.63636375 \\
\hline & $\bar{V}_{5 j}$ & 0.95 & 0.7772729 & 0.80606075 & 0.92121215 \\
\hline \multirow{2}{*}{$\begin{array}{l}\text { Long term } \\
\text { relationship }\end{array}$} & $\underline{V}_{6 j}$ & 0.48285705 & 0.5757141 & 0.48285705 & 0.52 \\
\hline & $\bar{V}_{6 j}$ & 0.72857155 & 0.85 & 0.72857155 & 0.7771431 \\
\hline
\end{tabular}


Table 15. $S^{\max }$ for alternatives according to Equation (15)

\begin{tabular}{|l|l|}
\hline \multirow{2}{*}{ Criteria } & $S^{\max }$ \\
\hline \multirow{2}{*}{ Commitment to quality } & 0.64411769 \\
\cline { 2 - 2 } & 0.88 \\
\hline \multirow{2}{*}{ Communication openness } & 0.55588239 \\
\cline { 2 - 2 } & 0.83 \\
\hline \multirow{2}{*}{ Reciprocal arrangement } & 0.5294118 \\
\cline { 2 - 2 } $\begin{array}{l}\text { Willingness to share } \\
\text { information in }\end{array}$ & 0.9537038 \\
\cline { 2 - 2 } $\begin{array}{l}\text { Supplier's effort } \\
\text { promoting JIT principles }\end{array}$ & 0.85 \\
\cline { 2 - 2 } Long term relationship & 0.95 \\
\cline { 2 - 2 } & 0.5757141 \\
\hline
\end{tabular}

Grey possibility degree according to Equation (16):

$\mathrm{P}\left(S_{1}<=\mathrm{SMAX}\right)=0.64467$

$\mathrm{P}\left(S_{2}<=\mathrm{SMAX}\right)=0.67407$

$\mathrm{P}\left(S_{3}<=\mathrm{SMAX}\right)=0.68636$

$\mathrm{P}\left(S_{4}<=\mathrm{SMAX}\right)=0.62019$

For which normalization is done according Table 16.

Table 16. Grey possibility degree normalized table.

\begin{tabular}{|l|l|l|}
\hline$S_{1}$ & 0.64467 & 0.245561 \\
\hline$S_{2}$ & 0.67407 & 0.25676 \\
\hline$S_{3}$ & 0.68636 & \\
\hline$S_{4}$ & 0.62019 & 0.261442 \\
\hline SUM & 2.62529 & 0.236237 \\
\hline
\end{tabular}




\section{Macrothink}

Assuming consideration of keeping the scores of the third and second periods stable, we will have (scores for each period may be different in case required). (According to Equation (18))

$0.245561 \mathrm{~s}_{12}+0.25676 \mathrm{~s}_{22}+0.261442 \mathrm{~s}_{32}+d_{2}^{-}-d_{2}^{-}=0.76376$

$0.245561 \mathrm{~s}_{13}+0.25676 \mathrm{~s}_{23}+0.261442 \mathrm{~s}_{33}+0.236237 \mathrm{~s}_{43}+d_{3}^{-}-d_{3}^{-}=1$.

The limitation of the number of suppliers in the third and second period based on the Equation (24):

$\mathrm{S}_{12}+\mathrm{S}_{22}+\mathrm{S}_{32} \leq 2$

$\mathrm{S}_{13}+\mathrm{S}_{23}+\mathrm{S}_{33}+\mathrm{S}_{43} \leq 3$

The limitation of the required amount based on the Equation (22) and Table 9 and 10:

$X_{12}+X_{22}+X_{32}=150$

$X_{13}+X_{23}+X_{33}+X_{43}=150$.

According to Equation (20) it will be as the following (the least budget):

$15 \mathrm{X}_{12}+20 \mathrm{X}_{22}+20 \mathrm{X}_{32}+20 \mathrm{X}_{13}+20 \mathrm{X}_{23}+20 \mathrm{X}_{33}+20 \mathrm{X}_{43}+e^{-}-e^{+}=0$.

Capacity limitation based on the Equation (23):

$10 \leq \mathrm{X}_{\mathrm{ij}} \leq 100$

And goals function according to Equation (25):

$\operatorname{Min}\left(a_{1} z_{1}+a_{2} z_{2}\right)=\operatorname{Min}\left(a_{1}\left(d_{1}^{+}+d_{2}^{+}\right)+a_{2} e^{+}\right)$

Ultimately, resolving the model using WINQSB Software will be in accordance with Table 17. 
Table 17. The result of planning and supplier selection

\begin{tabular}{|c|c|c|}
\hline Periods & suppliers & Ordered quantity \\
\hline \multirow{2}{*}{2} & 1 & 100 \\
\hline & 2 & 50 \\
\hline \multirow{3}{*}{3} & 4 & 100 \\
\hline & 1 & 40 \\
\hline & 2 & 10 \\
\hline
\end{tabular}

That ultimately, the least sum of costs for the periods 2 and 3 equals 5500 currency.

With respect to the derived result, it is obvious that in the second period, two suppliers are selected at most. In terms of cost, suppliers 1 and 2 may be selected respectively; in the third period, suppliers 4, 1 and 2 have the same conditions in terms of cost, in which items are selected according to the weights pertinent to the least function.

The final responses for the second and third periods were made available to commercial and procurement managers, and the mentioned individuals approved majority of the responses. Needless to mention that, since the designed model is in fact responsible for simulation of the current situation and according to the defined logical relationship, system's optimization is done. In other cases, acceptable responses may be also presented.

\section{Conclusions}

Despite numerous models of selecting suppliers proposed in the supply chain, a few could be adapted in real conditions. Therefore, the presented article attempts to introduce a model to consider all quality and quantity criteria and respective constraints. In this article, by using the grey theory and linguistics variables, quality criteria were converted to quantity equations. One of the biggest advantages of the grey theory is converting human judgments, particularly managers' experiences, and utilizing them in scoring the criteria and suppliers' alternatives and this was one of the items that were welcomed by the senior managers in the case study. This model was utilized in a big automotive company, which deals with many suppliers and supplying items and could prove efficiency and effectiveness as well as boosting the speed of decision-making. In addition, as it was observed, the process of selecting the suppliers is a dynamic one (as opposed to the previous models which would statically choose only one supplier for all the periods), in a way that this model is able to assess suppliers for different conditions in each period. As it is obvious from the adaptation of the model in the last sections, in addition to selecting suppliers, the model evaluates the purchase plan and works it out in every period.

With respect to future studies, it is suggested that the model's capability be improved through integration and combination with other techniques for flexibility in real-world environments.

\section{Acknowledgement}

The authors would like to thank the anonymous reviewers and the editor for their insightful 
comments and suggestions also appreciate of managing director ZAMYAD Company (Mr. Hamidi).

\section{References}

Chai, J., Liu, J. N., \& Ngai, E. W. (2012). Application of decision-making techniques in supplier selection: A systematic. Expert Systems with Applications, 40(10), 3872-3885. http://dx.doi.org/10.1016/j.eswa.2012.12.040

Choi, J., Bai, S. X., Geunes, J., \& Romeijn, E. H. (2007). Manufacturing delivery performance for supply chain management. Mathematical and Computer Modelling , 45(1-2), 11-20. http://dx.doi.org/10.1016/j.mcm.2005.07.008

Deng, J. (1989). Introduction to Grey System Theory. The Journal Of Gery System, 1(1), $1-24$.

Díaz-Madroñero, M., Peidro, D., \& Vasant, P. (2010). Vendor selection problem by using an interactive fuzzy multi-objective approach with modified S-curve membership functions.

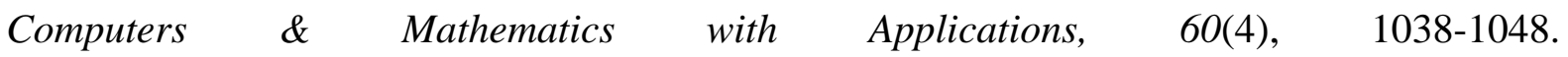
http://dx.doi.org/10.1016/j.camwa.2010.03.060

Dickson, G. W. (1966). An Analysis of Vendor Selection Systems and Decisions. International Journal of Purchasing and Materials Management, 2(1), 5.

Feng, B., Fan, Z. P., \& Li, Y. (2011). A decision method for supplier selection in multi-service outsourcing. International journal of production economics, 132(2), 240-251. http://dx.doi.org/10.1016/j.ijpe.2011.04.014

Golmohammadi, D., \& Mellat-Parast, M. (2012). Developing a grey-based decision-making model for supplier selection. International Journal of Production Economics, 137(2), 191-200. http://dx.doi.org/10.1016/j.ijpe.2012.01.025

Haa, S. H., \& Krishnanb, R. (2008). A hybrid approach to supplier selection for the maintenance of a competitive supply chain. Expert Systems with Applications, 34(2), 1303-1311. http://dx.doi.org/10.1016/j.eswa.2006.12.008

He, S., Chaudhry, S. S., \& Lei, Z. (2009). Stochastic vendor selection problem: chance-constrained model and genetic algorithms. Annals of Operations Research, 168, 169-179.

Heizer, J., \& Render, B. (2001). Principles of operations management. Upper Saddle River, N.J Prentice Hall.

Ho, W., Xu, X., \& Dey, P. K. (2010). Multi-criteria decision making approaches for supplier evaluation and selection: A literature review. European Journal of Operational Research, 202(1), 16-24. http://dx.doi.org/10.1016/j.ejor.2009.05.009 
Huang, G., \& Mak, K. (2000). A Web-Based Framework to Support Early Supplier Involvement in New Product Development. International Journal of Robotics and Computer Integrated Manufacture, 16, 169-179. http://dx.doi.org/10.1016/S0736-5845(00)00005-3

Kumar, M., Vrat, P., \& Shankar, R. (2006). A fuzzy programming approach for vendor selection problem in a supply chain. International Journal of Production Economics , 101(2), 273-285. http://dx.doi.org/10.1016/j.ijpe.2005.01.005

Pitchipoo, P., Venkumar, P., \& Rajakarunakaran, S. (2012). Fuzzy hybrid decision model for supplier evaluation and selection. International Journal of Production Research, 51(13), 3903-3919.

Rezaei, J., \& Ortt, R. (2013). Multi-criteria supplier segmentation using a fuzzy preference relations based AHP. European Journal of Operational Research, 225(1), 75-84. http://dx.doi.org/10.1016/j.ejor.2012.09.037

Sarkis, J., \& Talluri, S. (2002). A Model for Strategic Supplier Selection. The journal of supply chain management, $38(1), 18-28$.

Shyur, H., \& Shih, H. (2006). A hybrid MCDM model for strategic vendor selection. Mathematical and Computer Modelling, 447(7-8), 749-761. http://dx.doi.org/10.1016/j.mcm.2005.04.018

Tseng, M. L. (2009). A causal and effect decision making model of service quality expectation using grey-fuzzy DEMATEL approach. Expert Systems with Applications , 36(4), 7738-7748. http://dx.doi.org/10.1016/j.eswa.2008.09.011

Wang, T. Y., \& Yang, Y. H. (2009). A fuzzy model for supplier selection in quantity discount environments. Expert Systems with Applications, 36(10), 12179-12187. http://dx.doi.org/10.1016/j.eswa.2009.03.018

Wu, D. (2009). Supplier selection in a fuzzy group setting: A method using grey related analysis and Dempster-Shafer theory. Expert Systems with Applications, 36(5), 8892-8899. http://dx.doi.org/10.1016/j.eswa.2008.11.010 